Vol 4 No 1 (2021) 1-26 P-ISSN 2620-295 E-ISSN 2747-0490 DOI: $1047467 /$ elmal.v3i1.518

\title{
Dampak Inklusi Keuangan dan Bank Syariah terhadap Kesehatan dan Pendidikan Nasional
}

\author{
Ahmad Riswantio', Hendri Tanjung ${ }^{2}$, Abristadevi ${ }^{3}$ \\ 1,2Universitas Ibn Khaldun \\ riswantio16@gmail.com, hendri.tanjung@uika-bogor.ac.id, \\ abristasmart@gmail.com
}

\begin{abstract}
This study aims to analyze the impact of financial inclusion and Islamic banking on national health and education. The data used in this study is secondary data taken from the website of the financial services authority regarding Islamic banking statistics and data from the website of the Central Statistics Agency. The method used in this study is panel data regression analysis with the help of the Eviews 11 SV and StataSE 17 applications to obtain a complete description of the relationship between one variable and another. The sample in this study consisted of 33 provinces in Indonesia in the 2015-2020 period. The results of this study are that the inclusion variable does not have a significant effect on national health partially at the level of significance of more than $10 \%$. However, the financial inclusion variable has a significant effect on national education partially at the level of significance of less than 10\%. Islamic banks have a significant influence on national health partially at the level of significance of less than 10\%. However, Islamic banks do not have a significant influence on national education partially at the level of significance of more than $10 \%$. Then for the simultaneous regression, the results show that financial inclusion and Islamic banks jointly affect national health and education. The coefficient of determination of the two independent variables on national health is $84 \%$ while the remaining 16\% is explained or influenced by other factors that are not included in this research model. The coefficient of determination of financial inclusion and Islamic banking on national education is $4 \%$ while the remaining $96 \%$ is explained or influenced by other factors that are not included in this research model.
\end{abstract}

Keywords: Financial Inclusion, Islamic Banks, National Health, National Education

\section{ABSTRAK.}

Penelitian ini bertujuan untuk menganalisis dampak inklusi keuangan dan bank syariah terhadap kesehatan dan pendidikan nasional. Data yang digunakan dalam penelitian ini adalah data sukender yang diambil dari otoritas jasa keuanmgan mengenai statistik perbankan syariah dan data dari badan pusat statistik. Metode yang digunakan dalam penelitian ini adalah analisis regresi data panel dengan bantuan aplikasi Eviews 11 SV dan StataSE 17 untuk memperoleh yang lengkap mengenai hubungan antara variabel satu dengan variabel lain. Sampel dalam penelitian ini terdiri dari 33 provinsi di Indonesia dalam rentang waktu tahun 2015-2020. Hasil penelitian ini adalah bahwa variabel inklusi tidak memiliki pengaruh yang signifikan terhadap kesehatan nasional secara parsial pada level of significance lebih dari 10\%. Tetapi variabel inklusi keuangan memiliki pengaruh yang signifikan terhadap pendidikan nasional secara parsial pada level of significance kurang dari 10\%. Bank syariah memiliki pengaruh yang signifikan terhadap 


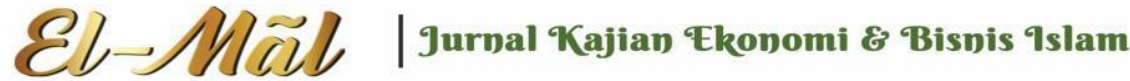

\section{Vol 4 No 1 (2021) 1-26 P-ISSN 2620-295 E-ISSN 2747-0490 DOI: 1047467/elmal.v3i1.518}

kesehatan nasional secara parsial pada level of significance kurang dari 10\%. Bank syariah tidak memiliki pengaruh yang signifikan terhadap pendidikan nasional secara parsial pada level of significance lebih dari $10 \%$. Lalu untuk regresi secara simultan memperoleh hasil bahwa inklusi keuangan dan bank syariah secara bersama-sama mempengaruhi kesehatan dan pendidikan nasional. Untuk koefisien determinasi dari dua variabel independen tersebut terhadap kesehatan nasional sebesar $84 \%$ sedangkan sisanya $16 \%$ dijelaskan atau dipengaruhi oleh faktor lain yang tidak dimasukkan kedalam model penelitian ini. Koefisien determinasi dari inklusi keuangan dan bank syariah terhadap pendidikan nasional sebesar 4\% sedangkan sisanya 96\% dijelaskan atau dipengaruhi oleh faktor lain yang tidak dimasukkan kedalam model penelitian ini.

Kata kunci: Inklusi Keuangan, Bank Syariah, Kesehatan Nasional, Pendidikan Nasional

\section{PENDAHULUAN}

Indonesia pun merupakan negara terpadat keempat didunia dengan populasi sekitar 276.006.371 jiwa (World Population Review, 2021) yang memiliki cita-cita keadilan sosial bagi seluruh rakyat Indonesia, cita-cita tersebut tercantum pada Pancasila dalam sila kelima. Namun sayangnya dalam usia ke-75, Indonesia nampaknya belum dapat meraih cita-cita mulia tersebut. Salah satu permasalahan yang mengganggu tercapainya tujuan tersebut adalah belum maksimalnya pertumbuhan ekonomi Indonesia. Pendapat tersebut dikuatkan dengan infografis dari Badan Pusat Statistik (2021) mengenai Ekonomi Indonesia 2015 Turun sebesar 4,88 persen.

\section{Pertumbuhan Produk Domestik Bruto (PDB) 2014-2019}

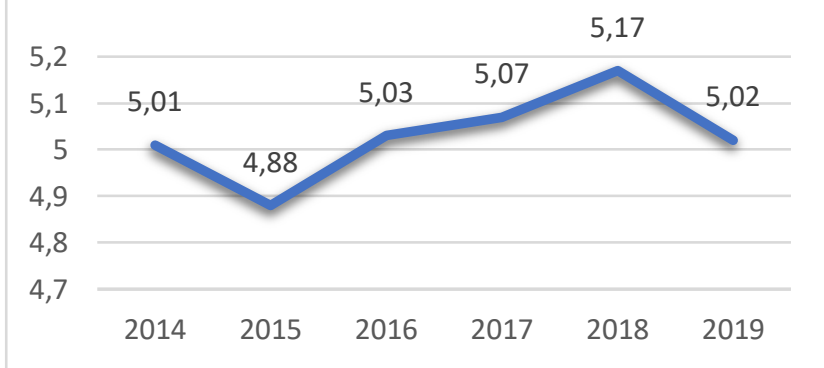

Gambar 1 Pertumbuhan PDB Indonesia 2014-2020

Sumber: Badan Pusat Statistik, Februari 2021

Salah satu cara untuk mengatasi hal tersebut Negara Kesatuan Republik Indonesia telah menetapkan strategi nasional untuk sektor keuangan di Indonesia yaitu Strategi Nasional Keuangan Inklusi. Aturan tersebut terlampir pada Peraturan Presiden Republik Indonesia Nomor 82 Tahun 2016 tentang Strategi Nasional Keuangan Inklusi. Menurut Perpres RI No. 82 Tahun 2016 Tentang Strategi Nasional Keuangan Inklusif (2016) strategi ini dibuat untuk memperluas akses masyarakat terhadap layanan 


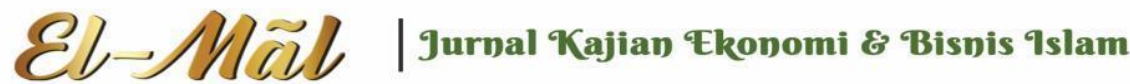

\section{Vol 4 No 1 (2021) 1-26 P-ISSN 2620-295 E-ISSN 2747-0490 DOI: $1047467 /$ elmal.v3i1.518}

keuangan dan strategi ini dibuat sebagai pedoman kementrian/lembaga untuk membuat strategis agar dapat mempercepat pertumbuhan ekonomi, percepatan penanggulangan kemiskinan, pengurangan kesenjangan antarindividu atau antardaerah dalam rangka mewujudkan kesejahteraan masyarakat Indonesia.

Populasi muslim di Indonesia sekitar 229.000.000 jiwa (World Population Review, 2021), angka tersebut menunjukan bahwa negara Indonesia mayoritas rakyatnya adalah muslim maka sudah seharusnya lembaga keuangan inklusif itu berbasis syariah. Lembaga keuangan inklusif syariah ini adalah seluruh lapisan masyarakat dapat mengakses lembaga keuangan syariah tanpa memandang derajat sosial.

Data yang diperoleh dari OJK - Laporan Perkembangan Keuangan Syariah Indonesia 2019 ini terlihat adanya kenaikan dalam jumlah rekening tabungan pada Bank Syariah. Tentu hal yang terlihat bagus tetapi, bukan berarti Lembaga Keuangan Syariah atau Perbankan Syariah di Indonesia sudah sangat inklusif untuk masyarakat Indonesia. Karena dibandingkan dengan populasi muslim di Indonesia tentu jumlah itu sangatlah kecil.

Tabel 1 Jumlah Rekening DPK Perbankan Syariah 2015-2019

Sumber: Otoritas Jasa Keuangan, September 2020

\begin{tabular}{|c|c|c|c|c|c|}
\hline $\begin{array}{c}\text { Jumlah } \\
\text { Rekening } \\
\text { (Dalam } \\
\text { Ribuan) }\end{array}$ & $\begin{array}{c}\text { TAHUN } \\
2015\end{array}$ & $\begin{array}{c}\text { TAHUN } \\
2016\end{array}$ & $\begin{array}{c}\text { TAHUN } \\
2017\end{array}$ & $\begin{array}{c}\text { TAHUN } \\
2018\end{array}$ & $\begin{array}{c}\text { TAHUN } \\
\mathbf{2 0 1 9}\end{array}$ \\
\hline Giro & 179 & 301 & 259 & 288 & $\mathbf{3 2 0}$ \\
\hline Tabungan & 18010 & 21587 & 25240 & 28406 & $\mathbf{3 3 0 0 1}$ \\
\hline Deposito & 293 & 311 & 338 & 374 & $\mathbf{4 6 5}$ \\
\hline
\end{tabular}

Google, Temasek , Bain \& Company, (2019) mengemukakan hasil riset yang berjudul Fulfilling its Promise - sThe Future of Southeast Asia's Digital Financial Services, sebanyak 92 juta jiwa penduduk dewasa di Indonesia belum memiliki rekening tabungan diperbankan. Jumlah tersebut lebih dari separuh total penduduk dewasa yang mencapai 181 juta jiwa. 


\section{Vol 4 No 1 (2021) 1-26 P-ISSN 2620-295 E-ISSN 2747-0490 DOI: $1047467 /$ elmal.v3i1.518}

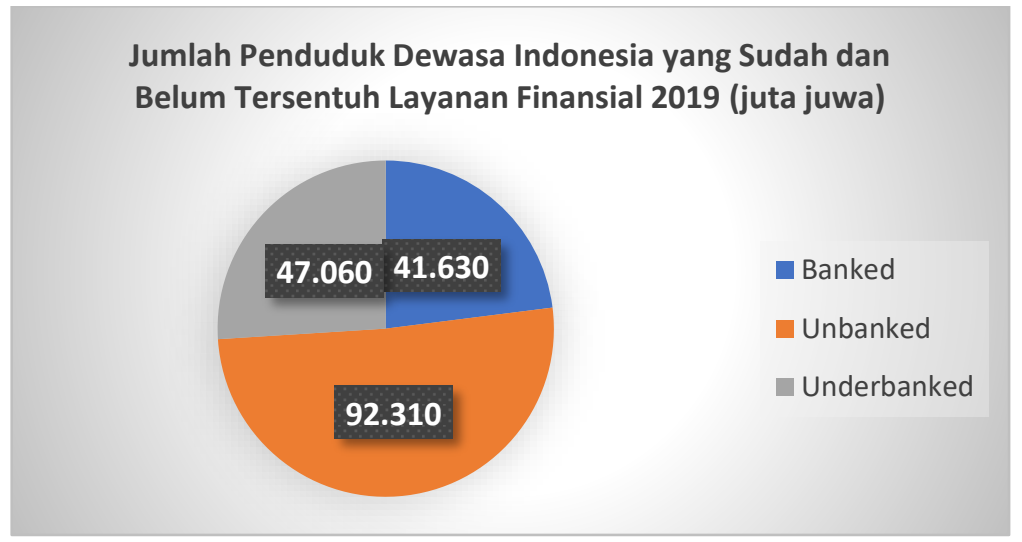

\section{Gambar 1 Jumlah Penduduk Dewasa Indonesia yang Sudah dan Belum Tersentuh Layanan Finansial 2019}

Sumber: Laporan Fulfilling its Promise - The Future of Southeast Asia's Digital Financial Services, Oktober 2019.

Nampaknya perannya harus terus ditingkatkan lagi oleh seluruh stakeholder yang bertanggung jawab dalam program ini. Menurut Nasution yang dikutip dari Abdul Rasyid (2016) Bank Indonesia memperkenalkan program National Strategy for Financial Inclusion (NSFI) sebagai bentuk upaya memperluas akses masyarakat terhadap jasa keuangan terhadap masyarakat yang membutuhkan akses lembaga keuangan (unbanked).

Inklusi keuangan dan Bank Syariah sangat erat hubungannya dengan sektor pendidikan dan kesehatan karena dalam Peraturan Presiden Republik Indonesia Nomor 82 Tahun 2016 tentang Strategi Nasional Keuangan Inklusi bahwa salah satu misi dan visi keuangan inklusif adalah mendorong pencapaian sustainable development goals (SDGs). Namun, pendidikan Indonesia jika dibandingan dengan negara Asean lainnya masih kurang begitu baik karena menurut data dari United Nations Development Programme (2020) Index Pendidikan pada tahun 2019, Indonesia berada di peringkat 6 dari 11 negara ASEAN dan Indonesia berada dibawah negara tetangga sepeti Singapura, Malaysia dan Brunei Darussalam. 


\section{Vol 4 No 1 (2021) 1-26 P-ISSN 2620-295 E-ISSN 2747-0490 DOI: $1047467 /$ elmal.v3i1.518}

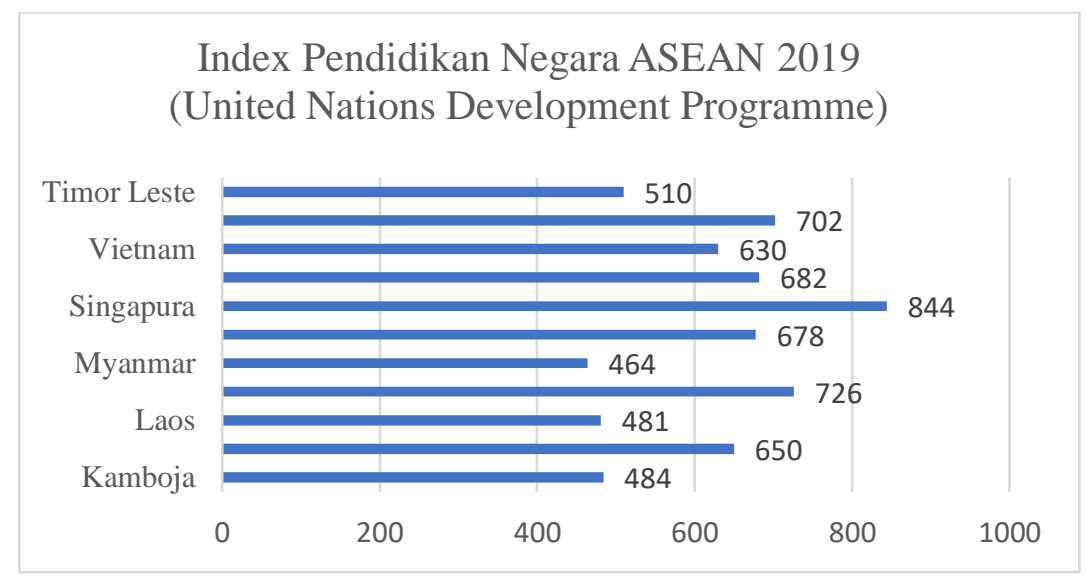

Gambar 2 Index Pendidikan Negara ASEAN

Sumber: United Nations Development Programme, Juli 2020

Index diatas menunjukan bahwa pendidikan di negara Indonesia masih kurang optimal dibandingkan dengan negara lainnya seperti: Singapura, Thailand, Brunei Darussalam, Malaysia dan Filipina.

Sedangkan, kesehatan Indonesia jika dibandingkan dengan negara Asean lainnya pun masih kurang begitu baik karena jika dilihat data dari United Nations Development Programme (2020) Index Harapan Hidup pada tahun 2019, Indonesia berada di peringkat 6 dari 11 negara ASEAN. Index dibawah menunjukan bahwa masyarakat Indonesia belum memiliki angka harapan hidup yang baik jika dibandingkan dengan negara tetangga seperti Singapura dan Malaysia.

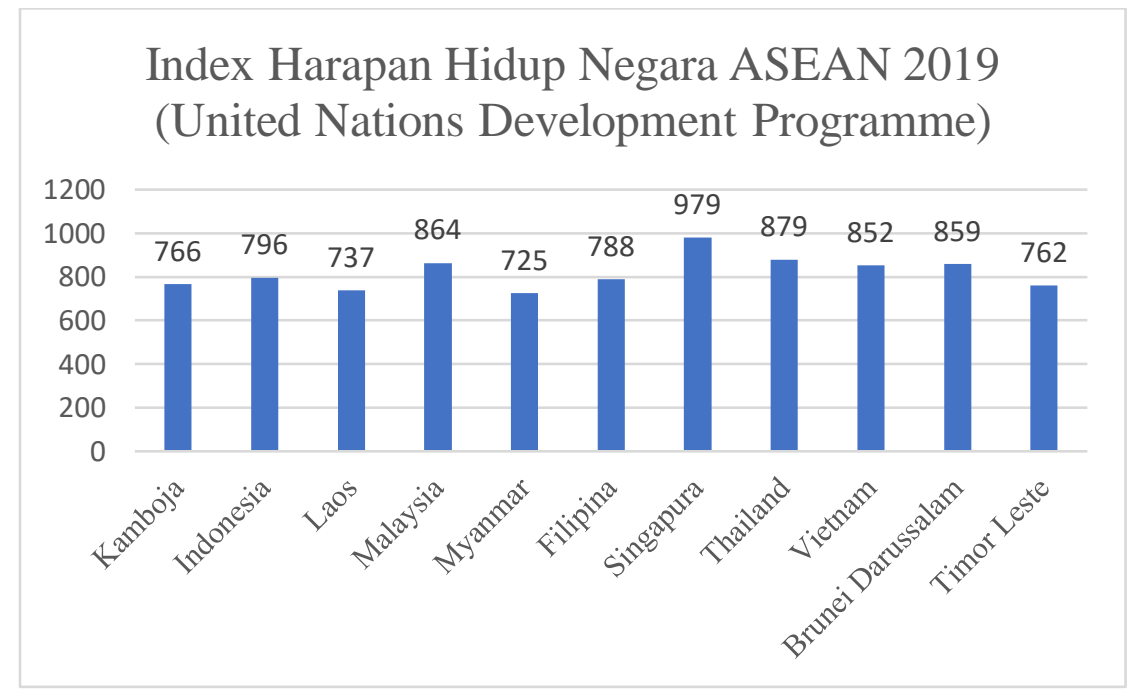

Gambar 3 Index Harapan Hidup Negara ASEAN 2019

Sumber: United Nations Development Programme, April 2020 


\section{Vol 4 No 1 (2021) 1-26 P-ISSN 2620-295 E-ISSN 2747-0490 DOI: $1047467 /$ elmal.v3i1.518}

Index diatas menunjukan bahwa kesehatan (angka harapan hidup) di negara Indonesia masih kurang optimal dibandingkan dengan negara lainnya seperti: Singapura, Thailand, Brunei Darussalam, Malaysia dan Vietnam.

Rendahnya index pendidikan dan kesehatan Indonesia dibandingkan dengan negara Asean lainnya dapat menjadi permasalahan yang amat buruk jika tidak ditangani dengan baik. Upaya yang telah dilakukan adalah dengan cara penerapan Keuangan Inklusi dengan diresmikannya Peraturan Presiden Republik Indonesia Nomor 82 Tahun 2016 tentang Strategi Nasional Keuangan Inklusi. Program yang telah dibuat haruslah dilihat kembali apakah memiliki dampak mengenai permasalah tersebut.

Penelitian ini ditujukan untuk melihat dampak dari program inklusi keuangan yang tentunya menggandeng bank syariah sebagai sarananya untuk memberikan dampak terhadap permasalah kesehatan dan pendidikan nasional. Adanya inklusi keuangan dan bank syariah menjadikan negara bisa untuk berikhtiar melakukan peningkatan atau perbaikan pada sektor kesehatan dan pendidikan nasional.

\section{TINJAUAN LITERATUR}

World Bank (2018) menyatakan bahwa inklusi keuangan ialah setiap individu atau bisnis dapat memiliki akses ke produk dan layanan jasa keuangan yang berguna dan terjangkau untuk memenuhi kebutuhan mereka seperti transaksi, pembayaran, kredit, asuransi dan tabungan yang disalurkan dengan bertanggung jawab dan berkelanjutan. Sedangkan menurut OJK (2019) inklusi keuangan memeiliki manfaat yang cukup banyak yaitu mendukung peningkatan human development index, mendukung stabilitas sistem keuangan, meningkatan efisiensi ekonomi, memberikan potensi pasar baru bagi perbankan, berkontribusi positif bagi pertumbuhan ekonomi lokal dan nasional yang menopang dan berkelanjutan.

Bank syariah sendiri memiliki definisi yang terdapat pada Undang-Undang Republik Indonesia Nomor 21 Tahun 2008 Tentang Perbankan Syariah yang dimaksud bank syariah adalah bank yang menjalankan aktivitas usahanya berdasarkan prinsip syariah dan menurut jenisnya terdiri dari Bank Umum Syariah dan Bank Pembiayaan Rakyat Syariah. Pembiayaan yang diberikan oleh bank syariah lebih bervariasi jika dibandingkan dengan kredit-kredit bank konvensional. Bank Syariah dapat dinamakan universal bank karena melakukan kegiatan investment bank dan commercial bank. Sebagai contoh, bank syariah dan unit usaha syariah dapat menyalurkan pembiayaan barang bergerak maupun barang tidak bergerak menggunakan akad ijarah (sewa) dan sewa beli dalam akad ijarah muntahiya bittamlik (Wangsawidjaja, 2012). Dapat disimpulkan dari definisi diatas bahwa bank syariah adalah lembaga keuangan yang salah satu tugasnya menyalurkan pembiayaan syariah dan pembiayaan merupakan salah satu program dari inklusi keuangan, dengan itu dapat dikatakan bahwa bank syariah 


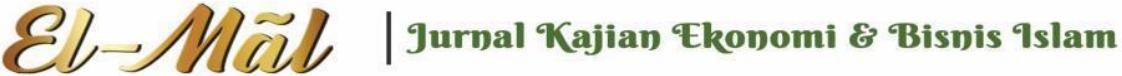

\section{Vol 4 No 1 (2021) 1-26 P-ISSN 2620-295 E-ISSN 2747-0490 DOI: 1047467/elmal.v3i1.518}

bagian dari inklusi keuangan karena bank syariah sebagai lembaga yang menyalurkan program inklusi keuangan.

Adanya inklusi keuangan dan bank syariah dapat dikatakan erat hubungan nya dengan kesehatan dan pendidikan karena dalam Peraturan Presiden Republik Indonesia Nomor 82 Tahun 2016 tentang Strategi Nasional Keuangan Inklusi bahwa salah satu misi dan visi keuangan inklusif adalah mendorong pencapaian sustainable development goals (SDGs). SDGs merupakan sebuah rencana aksi global yang disepakati oleh pemimpin dunia untuk mengakhiri kemiskinan, mengurangi kesenjangan dan melindugi lingkungan (Sustainable Development Goals, 2017).

Menurut Hasan (2003), pendidikan terdapat dua sudut pandang. Sudut pandang yang pertama adalah berkaitan dengan rakyat atau warga negara. Rakyat memandang pendidikan sebagai suatu proses pewarisan atau penyaluran kebudayaan yang mengandungi nilai - nilai budaya oleh generasi tua kepada generasi muda secara berterusan supaya kelangsungan hidup sesebuah masyarakat dapat berlaku.

Pada sudut pandang yang kedua menjurus kepada individu. Menerusi sudut individu, pendidikan merupakan proses membangunkan dan mengilap potensi-potensi yang sememangnya ada pada diri manusia sehingga potensi-potensi tersebut dapat membantu mewujudkan kemampuan tertentu untuk membantu kehidupan manusia yang seimbang dan normal.

Salah satu fungsi inklusi keuangan adalah membuat masyarakat mampu untuk menggapai layanan Kesehatan atau berobat ke Rumah Sakit Negara ataupun Swasta. Menurut Undang-Undang nomor 36 tahun 2009, defnisi kesehatan adalah "keadaan sehat, baik secara fisik, mental, spiritual maupun sosial untuk memungkinkan setiap orang untuk hidup produktif secara sosial dan ekonomi".

Adanya hubungan antara inklusi keuangan dengan kesehatan dan pendidikan telah dibuktikan oleh sejumlah penelitian terdahulu. Ajefu, Demir, \& Haghpanahan (2020) yang membahas tentang Dampak dari Inklusi Keuangan terhadap Kesehatan Mental berkesimpulan inklusi keuangan dapat dianggap sebagai kebijakan penting dalam mengatasi atau mengekang kejadian gejala depresi di Nigeria, terutama jika menyangkut rumah tangga pedesaan. Penelitian kedua yang dilakukan di Indonesia oleh Simatupang, M., Bonar M Sinaga., Sri Hartoyo., Harianto. (2020) yang membahas tentang Dampak Inklusi Keuangan, Pengeluaran Pemerintah di Bidang Pendidikan dan Kesehatan terhadap Pembangunan Manusia di Indonesia yang mengemukakan bahwa inklusi keuangan berdampak positif pada komponen indeks pembangunan manusia seiring dengan pengeluaran pemerintah di bidang pendidikan dan kesehatan.

Dalam penelitian Sukmawidjaja (2018) yang membahas tentang Dampak kegiatan inklusi keuangan terhadap pengembangan usaha Mikro dan kecil, pembangunan manusia (pendidikan dan kesehatan), dan pertumbuhan ekonomi di Indonesia, penelitian tersebut menghasilkan salah satunya bahwa Pembiayaan qard 


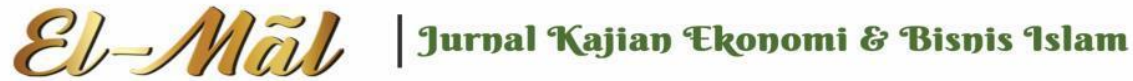

\section{Vol 4 No 1 (2021) 1-26 P-ISSN 2620-295 E-ISSN 2747-0490 DOI: 1047467/elmal.v3i1.518}

berpengaruh positif dan signifikan terhadap angka harapan hidup dan angka partisipasi sekolah. Penelitian dari Chiapa, \& Parker (2016) yang meneliti mengenai Dampak Inklusi Keuangan terhadap Sekolah Anak dan Aspirasi dan Harap Orang Tua dan untuk penelitian ini menemukan hasil salah satunya bahwa rekening tabungan membantu orang tua memiliki aspirasi dan harapan yang meningkat untuk pendidikan anak perempuan mereka tetapi ada penurunan untuk anak laki-laki meskipun tidak signifikan.

Agustin, G. (2020) meneliti mengenai Analisis Pengaruh Inklusi Keuangan Terhadap Indeks Pembangunan Manusia Di Indonesia Tahun 2015-2018. Hasil analisis menunjukkan bahwasanya secara parsial variabel penetrasi dan usability berpengaruh positif signifikan terhadap Indeks Pembangunan Manusia (Pendidikan dan Kesehatan) di Indonesia. Sedangkan variabel ketersediaan berpengaruh negatif signifikan terhadap Indeks Pembangunan Manusia di Indonesia. Secara simultan ketiga variabel keuangan inklusif berpengaruh signifikan terhadap Indeks Pembangunan Manusia di Indonesia.

\section{METODE PENELITIAN}

Penelitian ini menggunakan data sekunder berupa laporan Statistik Perbankan Syariah yang dikeluarkan oleh Otoritas Jasa Keuangan dan publikasi Badan Pusat Statistik dari tahun 2015-2020. Waktu untuk penelitian dimulai pada bulan Maret 2021 dam selesai pada bulan Agustus 2021. Penelitian ini menggunakan pendekatan asosiatif dan bersifat kuantitatif dengan data berbentuk data panel berupa 33 provinsi di Indonesia selama tahun 2015-2020. Data panel ini digunakan untuk mencari hubungan antara variabel independen yang terdiri dari inklusi keuangan (kepemilikan rekening syariah) dan bank syariah (pembiayaan perbankan syariah) terhadap variabel dependen yaitu kesehatan nasional (unmet need pelayanan kesehatan) dan pendidikan nasional (angka melek huruf penduduk berumur 15 tahun ke atas).

Definisi operasional variabel selain digunakan untuk memperjelas arti atau pengertian dari suatu istilah dalam pertanyaan penelitian, juga dapat digunakan untuk memberi petunjuk bagi orang lain bagi orang lain yang ingin melakukan hal yang serupa dalam penelitiannya berdasarkan beberapa variabel yang digunakan (Radjab \& Jam'an, 2017). Adapun definisi operasional dari beberapa variabel pada penelitian ini sebagai berikut:

Tabel 2 Definisi Operasional Variabel

\begin{tabular}{|c|c|c|c|c|}
\hline No. & Variabel & Definisi & Indikator & Skala \\
\hline 1 & $\begin{array}{l}\text { Kepemilikan } \\
\text { Rekening } \\
\text { Syariah }\left(\mathrm{X}_{1}\right)\end{array}$ & $\begin{array}{l}\text { Masyarakat yang mempunyai } \\
\text { rekening dari perbankan } \\
\text { syariah. }\end{array}$ & $\begin{array}{c}\text { Kepemilikan Rekening } \\
\text { Syariah (Transformasi } \\
\text { dalam bentuk } \\
\text { Logaritma Natural) }\end{array}$ & Rasio \\
\hline 2 & $\begin{array}{c}\text { Pembiayaan } \\
\text { Perbankan }\end{array}$ & $\begin{array}{c}\text { Masyarakat yang dapat } \\
\text { mengakses layanan }\end{array}$ & $\begin{array}{c}\text { Pembiayaan } \\
\text { Perbankan Syariah }\end{array}$ & Rasio \\
\hline
\end{tabular}




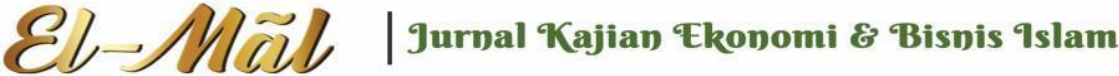

\section{Vol 4 No 1 (2021) 1-26 P-ISSN 2620-295 E-ISSN 2747-0490 DOI: $1047467 /$ elmal.v3i1.518}

\begin{tabular}{|c|c|c|c|c|}
\hline & Syariah $\left(\mathrm{X}_{2}\right)$ & $\begin{array}{l}\text { pembiayaan syariah dari bank } \\
\text { syariah }\end{array}$ & $\begin{array}{c}\text { (Transformasi dalam } \\
\text { bentuk Logaritma } \\
\text { Natural) }\end{array}$ & \\
\hline 2 & $\begin{array}{l}\text { Kesehatan } \\
\quad\left(\mathrm{Y}_{1}\right)\end{array}$ & $\begin{array}{l}\text { Keadaan sehat, baik secara } \\
\text { fisik, mental, spiritual } \\
\text { maupun sosial untuk } \\
\text { memungkinkan setiap orang } \\
\text { untuk hidup produktif secara } \\
\text { sosial dan ekonomi }\end{array}$ & $\begin{array}{l}\text { Persentase Unmet } \\
\text { Need Pelayanan } \\
\text { Kesehatan }\end{array}$ & Rasio \\
\hline 4 & $\begin{array}{l}\text { Pendidikan } \\
\left(\mathrm{Y}_{2}\right)\end{array}$ & $\begin{array}{c}\text { Didefinisikan oleh Imam } \\
\text { Ghazali pendidikan sebagai } \\
\text { proses yang harus dilalui oleh } \\
\text { manusia untuk } \\
\text { memberdayakan dirinya } \\
\text { sendiri }\end{array}$ & $\begin{array}{l}\text { Persentase Angka } \\
\text { Melek Huruf } \\
\text { Penduduk Berumur } \\
15 \text { Tahun Ke Atas }\end{array}$ & Rasio \\
\hline
\end{tabular}

Kemudian untuk model regresi data panel dalam penelitian ini adalah sebagai berikut:

$Y_{1 t i}=\alpha+b_{1} X_{1 t i}+b_{2} X_{2 t i}+e$
$Y_{2 t i}=\alpha+b_{1} X_{1 t i}+b_{2} X_{2 t i}+e$

Untuk pengolahan data pada penelitian ini menggunakan software Eviews 11 SV dan StataSE 17. Dalam mengolah data ini melalui berbagai macam tahapan. Dimulai dari statistik deskriptif, estimasi model terbaik untuk digunakan. Apakah Common Effect Model, Fixed Effect Model atau Random Effect Model melalui uji chow, uji hausman dan uji lagrange multiplier. Selanjutnya melakukan uji asumsi klasik dan pengujian koefisien jalur secara parsial, silmultan dan koefisien determinasi. Menurut Wahyono (2009) Analisis statistik deskriptif adalah merupakan salah satu bidang ilmu yang mempelajari cara-cara pengumpulan, penyusunan dan penyajian data penelitian.

Untuk uji chow terdapat kententuan, jika nilai prob. cross-section chi-square lebih kecil dari 0,05 maka yang dipilih adalah Fixed Effect Model, jika nilai probabilitasnya lebih besar dari 0,05 maka model yang dapat dipilih adalah Common Effect Model (Muna, 2019). Selanjutnya pada uji hausman, jika jika nilai nya lebih kecil dari 0,05 maka yang dipilih adalah Fixed Effect Model, jika nilai probabilitasnya lebih besar dari 0,05 maka model yang dapat dipilih adalah Random Effect Model (Muna, 2019). Kemudian pada uji lagrange multiplier, jika nilai nya lebih kecil dari 0,05 maka yang dipilih adalah Random Effect Model, jika nilai Both dari 0,05 maka model yang dapat dipilih adalah Common Effect Model (Muna, 2019). 


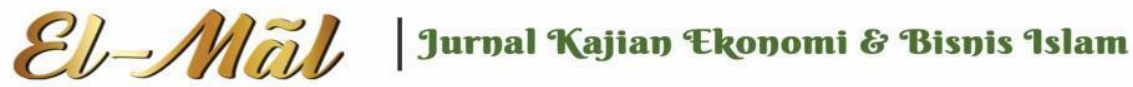

\section{Vol 4 No 1 (2021) 1-26 P-ISSN 2620-295 E-ISSN 2747-0490 DOI: $1047467 /$ elmal.v3i1.518}

Selanjutnya adalah uji asumsi klasik, Menurut Basuki (Akbary, 2017) mengemukakan bahwa uji asumsi klasik yang digunakan dalam regresi linier dengan pendekatan Ordinary Least Squared (OLS) meliputi uji Linieritas, Autokorelasi, Heteroskedastisitas, Multikolinieritas dan Normalitas, Namun, dalam model data panel tidak semua uji diperlukan. 1) Karena model telah diasumsikan bersifat linier, maka uji linieritas hampir tidak dilakukan pada model regresi linier. 2) Pada syarat BLUE (Best Linier Unbias Estimator), uji normalitas tidak termasuk didalamnya, dan ada beberapa pendapat juga tidak mengharuskan syarat ini sebagai sesuatu yang wajib dipenuhi. 3) Kondisi data yang mengandung heteroskedastisitas biasanya terjadi pada data cross section, yang mana data panel lebih dekat ke ciri data cross section jika dibandingkan time series. Menurut Gujarati (Satria,2016) mengatakan terdapat keuntungan dalam data panel salah satunya adalah sedikit terjadi multikolinieritas. Maka berdasarkan uraian diatas asumsi klasik yang digunakan dalam penelitian ini adalah uji heteroskedastisitas dan uji autokorelasi.

Setelah itu, dilakukan uji statistik t (siginifikansi parsial) untuk melihat ada atau tidaknya signifikansi dari pengaruh individu variabel independen terhadap variabel dependen dengan menganggap variabel lain bersifat konstan (Srihardianti, Mustafid, \& Prahutama 2016). Kemudian, melakukan uji statistik f (simultan) digunakan untuk menguji hasil estimasi model regresi apakah variabel independen secara bersamaan mempengaruhi variabel dependen (Srihardianti, Mustafid, \& Prahutama 2016). Lalu, melakukan Uji R² (koefisien determinasi) Menurut Gujarati (Fairuz, 2017) loefisien determinasi atau uji R2 pada intinya mengukur seberapa jauh kemampuan model dalam menerangkan variasi variabel independen.

\section{HASIL DAN PEMBAHASAN}

Hasil Statistik deskriptif dibawah menunjukan bahwa variabel Inklusi Keuangan $\left(\mathrm{X}_{1}\right)$, nilai observations menunjukan 198 yang diperoleh dari 33 objek penelitian dikalikan periode penelitian 6 tahun. Selain itu, dalam waktu 6 tahun nilai mean sebesar 7,758679 , median 7,731288, lalu dengan nilai maksimum sebesar 12,77900 , serta nilai minimum sebesar 4,709530, dan standar deviasi sebesar 1,716717.

\section{Tabel 3 Statistik Deskriptif}

Sumber: Data diolah menggunakan Eviews Sv 11 


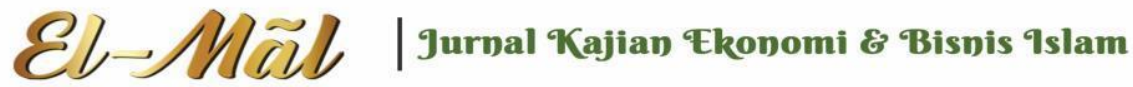

Vol 4 No 1 (2021) 1-26 P-ISSN 2620-295 E-ISSN 2747-0490 DOI: $1047467 /$ elmal.v3i1.518

\begin{tabular}{|c|c|c|c|c|}
\hline & INKLUSI_KEUANGAN & BANK_SYARIAH & KESEHATAN & PENDIDIKAN \\
\hline Mean & 7.758679 & 7.759653 & 5.107323 & 96.00621 \\
\hline Median & 7.731288 & 8.011506 & 4.805000 & 97.92500 \\
\hline Maximum & 12.77900 & 11.97273 & 9.320000 & 99.87000 \\
\hline Minimum & 4.709530 & 4.574711 & 2.410000 & 70.83000 \\
\hline Std. Dev. & 1.716717 & 1.665239 & 1.494277 & 4.824386 \\
\hline Observations & 198 & 198 & 198 & 198 \\
\hline
\end{tabular}

Penentuan model estimasi data panel dan Pengujian Hipotesis model $1\left(\mathrm{Y}_{1 \mathrm{ti}}=\alpha+\right.$ $\mathrm{b}_{1} \mathrm{X}_{1 \mathrm{ti}}+\mathrm{b}_{2} \mathrm{X}_{2 \mathrm{ti}}+\mathrm{e}$ ) dilakukan melalui uji chow dan uji hausman. Dalam uji chow menunjukan bahwa nilai Prob. Cross-section Chi-square adalah 0,00<0,05, maka model yang terpilih adalah Fixed Effect Model.

Tabel 4 Uji Chow Model 1

Sumber: Data diolah menggunakan Eviews Sv 11

\begin{tabular}{|c|c|c|c|}
\hline Effects Test & Statistic & d.f. & Prob. \\
\hline Cross-section F & 29.172719 & $(32,163)$ & 0.0000 \\
\hline Cross-section Chi-square & 377.418295 & 32 & 0.0000 \\
\hline
\end{tabular}

Selanjutnya akan dilakukan uji hausman. Apabila nilai Prob.Chi-square $>0,05$ maka $\mathrm{h}_{0}$ diterima yang berarti model Random Effect Model yang tepat digunakan. Jika nilai Prob.Chi-square $<0,05$ maka $_{1}$ diterima yang berarti model Fixed Effect Model yang tepat digunakan.

Tabel 5 Uji Hausman Model 1

Sumber: Data diolah menggunakan Eviews Sv 11

\begin{tabular}{|c|c|c|c|}
\hline Test Summary & Chi-Sq. Statistic & Chi-Sq. d.f. & Prob. \\
\hline Cross-section random & 19.268439 & 2 & 0.0001 \\
\hline
\end{tabular}

Berdasarkan hasil uji hausman diatas, dapat dilihat dari nilai Prob.Cross.section random sebesar 0,0001<0,05, ini berarti H0 ditolak dan H1 diterima sehingga model yang cocok adalah Fixed Effect Model. 


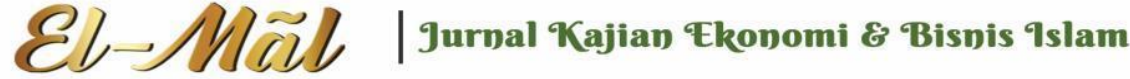

\section{Vol 4 No 1 (2021) 1-26 P-ISSN 2620-295 E-ISSN 2747-0490 DOI: $1047467 /$ elmal.v3i1.518}

Untuk uji t pada model $1\left(\mathrm{Y}_{1 \mathrm{ti}}=\alpha+\mathrm{b}_{1} \mathrm{X}_{1 \mathrm{ti}}+\mathrm{b}_{2} \mathrm{X}_{2 \mathrm{ti}}+\mathrm{e}\right)$ memberikan hasil sebagai berikut:

Tabel 6 Uji T Model 1

Sumber: Data diolah menggunakan Eviews Sv 11

\begin{tabular}{|c|c|c|c|c|}
\hline \multicolumn{5}{|c|}{$\begin{array}{l}\text { Dependent Variable: Y1 } \\
\text { Method: Panel Least Squares } \\
\text { Date: } 07 / 13 / 21 \text { Time: } 11: 14 \\
\text { Sample: } 20152020 \\
\text { Periods included: } 6 \\
\text { Cross-sections included: } 33 \\
\text { Total panel (balanced) observations: } 198\end{array}$} \\
\hline Variable & Coefficient & Std. Error & t-Statistic & Prob. \\
\hline $\mathrm{C}$ & 0.486833 & 1.247168 & 0.390350 & 0.6968 \\
\hline LN_X1 & 0.082652 & 0.210033 & 0.393519 & 0.6945 \\
\hline LN_X2 & 0.512809 & 0.273197 & 1.877067 & 0.0623 \\
\hline
\end{tabular}

a) Hasil uji-t pada variabel inklusi keuangan terhadap kesehatan nasional terlihat nilai probabilitasnya sebesar 0,6945 yang artinya $>0,1$, sehingga dapat disimpulkan bahwa variabel inklusi keuangan tidak memiliki pengaruh yang signifikan terhadap kesehatan nasional. Artinya $\mathrm{H}_{0}$ diterima dan $\mathrm{H}_{1}$ ditolak.

b) Hasil uji-t pada variabel bank syariah terhadap kesehatan nasional terlihat nilai probabilitasnya sebesar 0,0623 yang artinya $<0,1$, sehingga dapat disimpulkan bahwa variabel bank syariah memiliki pengaruh yang signifikan terhadap kesehatan nasional. Artinya $\mathrm{H}_{0}$ ditolak dan $\mathrm{H}_{1}$ diterima. Lalu untuk nilai coefficient nya sebesar 0,512809 maka dapat diartikan jika terjadi kenaikan satu satuan terhadap variabel $\mathrm{X}_{2}$ maka akan menaikan variabel $\mathrm{Y}_{1}$ sebesar 0,512809.

Untuk uji f pada model $1\left(\mathrm{Y}_{1 \mathrm{ti}}=\alpha+\mathrm{b}_{1} \mathrm{X}_{1 \mathrm{ti}}+\mathrm{b}_{2} \mathrm{X}_{2 \mathrm{ti}}+\mathrm{e}\right)$ memberikan hasil sebagai berikut:

Tabel 7 Uji F Model 1

Sumber: Data diolah menggunakan Eviews Sv 11 


\section{Vol 4 No 1 (2021) 1-26 P-ISSN 2620-295 E-ISSN 2747-0490 DOI: $1047467 /$ elmal.v3i1.518}

\begin{tabular}{lrlr}
\hline \hline \multicolumn{2}{l}{ Cross-section fixed (dummy variables) } & \\
\hline \hline Root MSE & 0.539566 & R-squared & 0.868953 \\
Mean dependent var & 5.107323 & Adjusted R-squared & 0.841618 \\
S.D. dependent var & 1.494277 & S.E. of regression & 0.594680 \\
Akaike info criterion & 1.957434 & Sum squared resid & 57.64411 \\
Schwarz criterion & 2.538693 & Log likelihood & -158.7859 \\
Hannan-Quinn criter. & 2.192708 & F-statistic & 31.78913 \\
Durbin-Watson stat & 2.010822 & Prob(F-statistic) & 0.000000 \\
\hline \hline
\end{tabular}

Berdasarkan hasil diatas dapat dilihat bahwa nilai probabilitas $\mathrm{f}$ (statistic) sebesar $0,000<0,05$, maka dapat disimpulkan bahwa inklusi keuangan dan bank syariah secara bersama-sama (simultan) mempengaruhi variabel dependen yaitu kesehatan nasional.

Koefisien Determinasi (Adjusted R-Squared) model $1\left(\mathrm{Y}_{1 \mathrm{ti}}=\alpha+\mathrm{b}_{1} \mathrm{X}_{1 \mathrm{ti}}+\mathrm{b}_{2} \mathrm{X}_{2 \mathrm{ti}}+\right.$ e) mengemukakan hasil sebegai berikut:

Tabel 8 Koefisien Determinasi (Adjusted R-Squared) Model 1 Sumber: Data diolah menggunakan Eviews Sv 11

\begin{tabular}{lrlr}
\multicolumn{4}{l}{ Cross-section fixed (dummy variables) } \\
\hline \hline Root MSE & 0.539566 & R-squared & 0.868953 \\
Mean dependent var & 5.107323 & Adjusted R-squared & 0.841618 \\
S.D. dependent var & 1.494277 & S.E. of regression & 0.594680 \\
Akaike info criterion & 1.957434 & Sum squared resid & 57.64411 \\
Schwarz criterion & 2.538693 & Log likelihood & -158.7859 \\
Hannan-Quinn criter. & 2.192708 & F-statistic & 31.78913 \\
Durbin-Watson stat & 2.010822 & Prob(F-statistic) & 0.000000 \\
\hline
\end{tabular}

Berdasarkan hasil tersebut dapat terlihat nilai Adjusted R-Squared sebesar 0,841618. Hasil tersebut dapat disimpulkan bahwa variabel Y1 dapat dijelaskan oleh X1 dan X2 sebesar 84\%, sedangkan sisanya (100\%-84\%=16\%) dijelaskan oleh variabel lain di luar model ini.

Kemudian, melakukan penentuan model estimasi data panel dan pengujian hipotesis model $2\left(\mathrm{Y}_{2 \mathrm{ti}}=\alpha+\mathrm{b}_{1} \mathrm{X}_{1 \mathrm{ti}}+\mathrm{b}_{2} \mathrm{X}_{2 \mathrm{ti}}+\mathrm{e}\right)$ dilakukan melalui uji chow, uji hausman dan Uji lagrange multiplier. Dalam uji chow menunjukan bahwa nilai Prob. Cross-section Chi-square adalah 0,00<0,05, maka model yang terpilih adalah Fixed Effect Model.

Tabel 9 Uji Chow Model 2

Sumber: Data diolah menggunakan Eviews Sv 11 


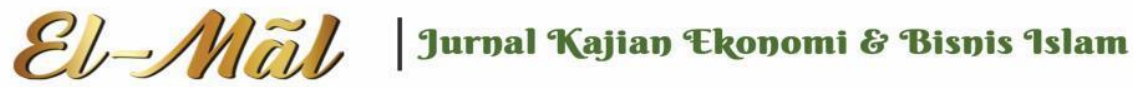

\section{Vol 4 No 1 (2021) 1-26 P-ISSN 2620-295 E-ISSN 2747-0490 DOI: $1047467 /$ elmal.v3i1.518}

\begin{tabular}{|c|c|c|c|}
\hline Effects Test & Statistic & d.f. & Prob. \\
\hline Cross-section F & 140.711474 & $(32,163)$ & 0.0000 \\
\hline Cross-section Chi-square & 664.142955 & 32 & 0.0000 \\
\hline
\end{tabular}

Selanjutnya akan dilakukan uji hausman. Apabila nilai Prob.Chi-square $>0,05$ maka $\mathrm{h}_{0}$ diterima yang berarti model Random Effect Model yang tepat digunakan. Jika nilai Prob.Chi-square $<0,05$ maka $_{1}$ diterima yang berarti model Fixed Effect Model yang tepat digunakan.

Tabel 10 Uji Hausman Model 2

Sumber: Data diolah menggunakan Eviews Sv 11

\begin{tabular}{lrrr}
\hline Correlated Random Effects - Hausman Test & & \\
Equation: MODEL_REM_Y2 \\
Test cross-section random effects & & & \\
\hline \hline Test Summary & Chi-Sq. Statistic & Chi-Sq. d.f. & Prob. \\
\hline \hline Cross-section random & 0.033232 & 2 & 0.9835 \\
\hline \hline
\end{tabular}

Berdasarkan hasil uji hausman diatas, dapat dilihat dari nilai Prob.Cross.section random sebesar $0,9835>0,05$, ini berarti $\mathrm{H}_{0}$ diterima dan $\mathrm{H}_{1}$ ditolak sehingga model yang cocok adalah Random Effect Model. Maka selanjutnya akan dilakukan uji lagrange multiplier. Uji lagrange multiplier dilakukan ketika uji hausman hasilnya $\mathrm{H}_{0}$ diterima. Selain itu, Uji lagrange multiplier dilakukan untuk menguji model yang lebih cocok untuk digunakan antara Common Effect Model dan Random Effect Model. Oleh karenanya dilakukan uji lagrange multiplier untuk mengetahuinya. Berikut hasil uji lagrange multiplier untuk model 2:

Tabel 11 Uji Lagrange Multiplier Model 2 Sumber: Data diolah menggunakan Eviews Sv 11 


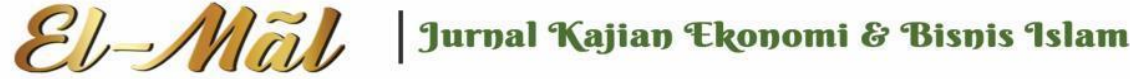

\section{Vol 4 No 1 (2021) 1-26 P-ISSN 2620-295 E-ISSN 2747-0490 DOI: $1047467 /$ elmal.v3i1.518}

\begin{tabular}{|c|c|c|c|}
\hline & \multicolumn{3}{|c|}{ Test Hypothesis } \\
\hline & Cross-section & Time & Both \\
\hline Breusch-Pagan & $\begin{array}{l}454.2877 \\
(0.0000)\end{array}$ & $\begin{array}{l}2.559635 \\
(0.1096)\end{array}$ & $\begin{array}{l}456.8474 \\
(0.0000)\end{array}$ \\
\hline Honda & $\begin{array}{l}21.31403 \\
(0.0000)\end{array}$ & $\begin{array}{c}-1.599886 \\
(0.9452)\end{array}$ & $\begin{array}{l}13.94000 \\
(0.0000)\end{array}$ \\
\hline King-Wu & $\begin{array}{l}21.31403 \\
(0.0000)\end{array}$ & $\begin{array}{c}-1.599886 \\
(0.9452)\end{array}$ & $\begin{array}{l}6.347328 \\
(0.0000)\end{array}$ \\
\hline Standardized Honda & $\begin{array}{l}22.29053 \\
(0.0000)\end{array}$ & $\begin{array}{c}-1.436574 \\
(0.9246)\end{array}$ & $\begin{array}{l}10.92719 \\
(0.0000)\end{array}$ \\
\hline Standardized King-Wu & $\begin{array}{l}22.29053 \\
(0.0000)\end{array}$ & $\begin{array}{c}-1.436574 \\
(0.9246)\end{array}$ & $\begin{array}{c}3.823200 \\
(0.0001)\end{array}$ \\
\hline Gourieroux, et al. & - & - & $\begin{array}{l}454.2877 \\
(0.0000)\end{array}$ \\
\hline
\end{tabular}

Apabila nilai Both Breusch-Pagan $>0,05$ maka $\mathrm{H}_{0}$ diterima yang berarti model

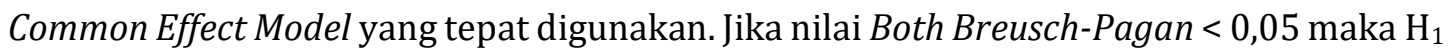
diterima yang berarti model Random Effect Model yang tepat digunakan. Berdasarkan hasil uji lagrange multiplier diatas, dapat dilihat dari nilai Both Breusch-Pagan sebesar $0,0000<0,05$, ini berarti $\mathrm{H}_{0}$ ditolak dan $\mathrm{H}_{1}$ diterima sehingga model yang cocok adalah Random Effect Model. berikut:

Untuk uji t pada model $2\left(\mathrm{Y}_{2 \mathrm{ti}}=\alpha+\mathrm{b}_{1} \mathrm{X}_{1 \mathrm{ti}}+\mathrm{b}_{2} \mathrm{X}_{2 \mathrm{ti}}+\mathrm{e}\right)$ memberikan hasil sebagai

Tabel 12 Uji T Model 2

Sumber: Data diolah menggunakan Eviews Sv 11

Dependent Variable: Y2

Method: Panel EGLS (Cross-section random effects)

Date: 07/13/21 Time: 12:11

Sample: 20152020

Periods included: 6

Cross-sections included: 33

Total panel (balanced) observations: 198

Swamy and Arora estimator of component variances

\begin{tabular}{crrrr}
\hline \hline Variable & Coefficient & Std. Error & t-Statistic & Prob. \\
\hline \hline C & 92.32367 & 2.020001 & 45.70478 & 0.0000 \\
LN_X1 & 0.775556 & 0.341864 & 2.268611 & 0.0244 \\
LN_X2 & -0.300884 & 0.426948 & -0.704731 & 0.4818
\end{tabular}




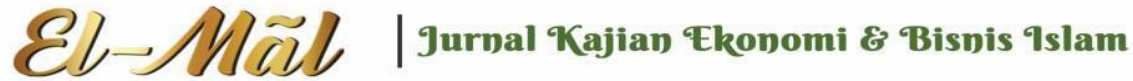

\section{Vol 4 No 1 (2021) 1-26 P-ISSN 2620-295 E-ISSN 2747-0490 DOI: $1047467 /$ elmal.v3i1.518}

a) Hasil uji-t pada variabel inklusi keuangan terhadap pendidikan nasional terlihat nilai probabilitasnya sebesar 0,0244 yang artinya $<0,1$, sehingga dapat disimpulkan bahwa variabel inklusi keuangam memiliki pengaruh yang signifikan terhadap pendidikan nasional. Artinya $\mathrm{H}_{0}$ ditolak dan $\mathrm{H}_{1}$ diterima. Lalu untuk nilai coefficient nya sebesar 0,775556 maka dapat diartikan jika terjadi kenaikan satu satuan terhadap variabel $\mathrm{X}_{1}$ maka akan menaikan variabel $Y_{2}$ sebesar 0,775556.

b) Hasil uji-t pada variabel bank syariah terhadap pendidikan nasional terlihat nilai probabilitasnya sebesar 0,4818 yang artinya $>0,1$, sehingga dapat disimpulkan bahwa variabel bank syariah tidak memiliki pengaruh yang signifikan terhadap pendidikan nasional. Artinya $\mathrm{H}_{0}$ diterima dan $\mathrm{H}_{1}$ ditolak.

Untuk uji f pada model $2\left(\mathrm{Y}_{2 \mathrm{ti}}=\alpha+\mathrm{b}_{1} \mathrm{X}_{1 \mathrm{ti}}+\mathrm{b}_{2} \mathrm{X}_{2 \mathrm{ti}}+\mathrm{e}\right)$ memberikan hasil sebagai berikut:

Tabel 13 Uji F Model 2

Sumber: Data diolah menggunakan Eviews Sv 11

\begin{tabular}{llll}
\hline \hline \multicolumn{4}{l}{ Weighted Statistics } \\
\hline \hline Root MSE & 0.967829 & R-squared & 0.048225 \\
Mean dependent var & 7.836800 & Adjusted R-squared & 0.038464 \\
S.D. dependent var & 0.994560 & S.E. of regression & 0.975245 \\
Sum squared resid & 185.4650 & F-statistic & 4.940218 \\
Durbin-Watson stat & 0.624442 & Prob(F-statistic) & 0.008074 \\
\hline \hline & Unweighted Statistics & \\
\hline \hline R-squared & 0.021510 & Mean dependent var & \multirow{2}{*}{96.00621} \\
Sum squared resid & 4486.488 & Durbin-Watson stat & 0.025814 \\
\hline \hline
\end{tabular}

Berdasarkan hasil diatas dapat dilihat bahwa nilai probabilitas $\mathrm{f}$ (statistic) sebesar 0,008 < 0,05, maka dapat disimpulkan bahwa inklusi keuangan dan bank syariah secara bersama-sama (simultan) mempengaruhi variabel dependen yaitu pendidikan nasional.

Koefisien Determinasi (Adjusted R-Squared) model $2\left(\mathrm{Y}_{2 \mathrm{ti}}=\alpha+\mathrm{b}_{1} \mathrm{X}_{1 \mathrm{ti}}+\mathrm{b}_{2} \mathrm{X}_{2 \mathrm{ti}}+\right.$ e) mengemukakan hasil sebegai berikut:

Tabel 14 Koefisien Determinasi (Adjusted R-Squared) Model 2 Sumber: Data diolah menggunakan Eviews Sv 11 


\section{Vol 4 No 1 (2021) 1-26 P-ISSN 2620-295 E-ISSN 2747-0490 DOI: $1047467 /$ elmal.v3i1.518}

\begin{tabular}{llll}
\hline \hline & \multicolumn{2}{l}{ Weighted Statistics } & \\
\hline \hline Root MSE & 0.967829 & R-squared & 0.048225 \\
Mean dependent var & 7.836800 & Adjusted R-squared & 0.038464 \\
S.D. dependent var & 0.994560 & S.E. of regression & 0.975245 \\
Sum squared resid & 185.4650 & F-statistic & 4.940218 \\
Durbin-Watson stat & 0.624442 & Prob(F-statistic) & 0.008074 \\
\hline \hline & Unweighted Statistics & \\
\hline \hline R-squared & 0.021510 & Mean dependent var & \multirow{2}{*}{96.00621} \\
Sum squared resid & 4486.488 & Durbin-Watson stat & 0.025814 \\
\hline \hline
\end{tabular}

Berdasarkan tabel 4.21 dapat terlihat nilai Adjusted R-Squared sebesar 0,038464. Hasil tersebut dapat disimpulkan bahwa variabel Y2 dapat dijelaskan oleh X1 dan X2 sebesar 4\%, sedangkan sisanya (100\%-4\%=96\%) dijelaskan oleh variabel lain di luar model ini.

Selanjutnya, melakukan uji autokorelasi dan uji Heteroskedastisitas untuk Model 1. Uji autokorelasi model 1 ini menggunakan uji durbin watson dengan metode praiswinsten dan juga menggunakan robust pada aplikasi Stata SE 17. Prais Winsten adalah pengembangan metode cochrane orcutt. Perbedaanya adalah jika cochrane orcutt, jumlah observasi berkurang satu, sebab perhitungan transformasi cochrane orcutt adalah berdasarkan LAG, yaitu pengurangan antara sample ke-i dengan sample ke-i-1. Dalam prais winsten, memiliki perhitungan khusus pada observasi kesatu, sehingga tidak ada observasi yang hilang (Hidayat, 2016).

Jika terjadi autokorelasi dalam panel maka dapat menggunakan robust standard error. Pendekatan ini biasanya diadopsi dalam literatur penggunaan robust standard errors (Ibrahim). Berikut hasil dari autokorelasi menggunakan uji durbin watson:

Tabel 15 Uji Autokorelasi Model 1

Sumber: Data diolah menggunakan Stata SE 17

\begin{tabular}{|c|c|c|c|c|c|c|}
\hline $\mathrm{y} 1$ & Coefficient & $\begin{array}{l}\text { Semirobust } \\
\text { std. err. }\end{array}$ & $\mathrm{t}$ & $P>|t|$ & [95\% conf. & interval] \\
\hline$x 1$ & -.1123187 & .1572393 & -0.71 & 0.476 & -.4224268 & .1977893 \\
\hline$x 2$ & .0001269 & .1865246 & 0.00 & 0.999 & -.3677377 & .3679914 \\
\hline _cons & 5.965557 & 1.024823 & 5.82 & 0.000 & 3.944397 & 7.986717 \\
\hline rho & .8493651 & & & & & \\
\hline
\end{tabular}

Durbin-Watson statistic (original) $\quad=0.278081$

Durbin-Watson statistic (transformed) $=2.178635$

Dari hasil pengujian tersebut terlihat bahwa nilai Durbin-watson statistic (transformed) sebesar 2.718635, maka tidak terjadi autokorelasi. Menurut Field (2011) 


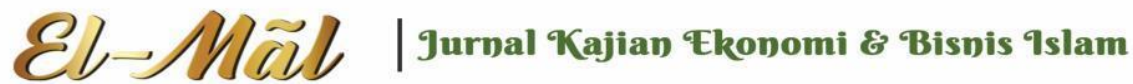

\section{Vol 4 No 1 (2021) 1-26 P-ISSN 2620-295 E-ISSN 2747-0490 DOI: $1047467 /$ elmal.v3i1.518}

ukuran statistik durbin watson aturan praktis yang sangat konservatif, nilai kurang dari 1 atau lebih besar dari 3 pasti menimbulkan kekhawatiran, maka dari itu nilai diantara 1 dan 3 tidak terjadi autokorelasi.

Selanjutnya, uji heteroskedastisitas dalam penelitian ini menggunakan uji glesjer. Hasil yang diperlukan dari uji ini adalah nilai prob.chi-square (yang Obs* ${ }^{*}$ Squared) harus lebih besar dari 0,05. Berikut hasil dari uji heteroskedastisitas yang dapat dilihat pada tabel 16.

Tabel 16 Uji Heteroskedastisitas Model 1

Sumber: Data diolah menggunakan Eviews Sv 11

Heteroskedasticity Test: Glejser

Null hypothesis: Homoskedasticity

\begin{tabular}{llll}
\hline \hline F-statistic & 4.310554 & Prob. F(2,195) & 0.0147 \\
Obs*R-squared & 8.383116 & Prob. Chi-Square(2) & 0.0151 \\
Scaled explained SS & 8.201142 & Prob. Chi-Square(2) & 0.0166 \\
\hline \hline
\end{tabular}

Berdasarkan hasil uji heteroskedastisitas diatas terlihat nilai prob.chi-square (yang Obs $^{*} R$ Squared) sebesar 0,0151<0,05, sehingga dapat disimpulkan bahwa terjadi heteroskedastisitas pada penelitian ini, maka harus dilakukan perbaikand dengan cara generate data. Maka setelah dilakukan perbaikan maka hasilnya sebagai berikut:

Tabel 17 Uji Heteroskedastisitas Model 1 setelah diperbaiki Sumber: Data diolah menggunakan Eviews Sv 11

\begin{tabular}{|c|c|c|c|}
\hline \multicolumn{4}{|c|}{$\begin{array}{l}\text { Heteroskedasticity Test: Glejser } \\
\text { Null hypothesis: Homoskedasticity }\end{array}$} \\
\hline F-statistic & 1.114325 & Prob. $F(2,194)$ & 0.3302 \\
\hline Obs*R-squared & 2.237411 & Prob. Chi-Square(2) & 0.3267 \\
\hline Scaled explained SS & 2.215699 & Prob. Chi-Square(2) & 0.3303 \\
\hline
\end{tabular}

Berdasarkan hasil uji heteroskedastisitas diatas terlihat nilai prob.chi-square (yang $0 b s^{*} R$ Squared) sebesar $03267>0,05$, sehingga dapat disimpulkan bahwa tidak terjadi heteroskedastisitas pada penelitian ini. Kemudian, melakukan uji autokorelasi dan uji Heteroskedastisitas untuk Model 2. Untuk Uji Autokorelasi Model 2 menggunakan uji Breusch-Godfrey. Penilaian dilihat dari nilai prob.chi-square(2). Jika nilai probabilitasnya $<0,05$ maka terjadi masalah autokorelasi. Berikut hasil autokorelasinya:

Tabel 18 Uji Uji Autokorelasi Model 2 Sumber: Data diolah menggunakan Eviews Sv 11 


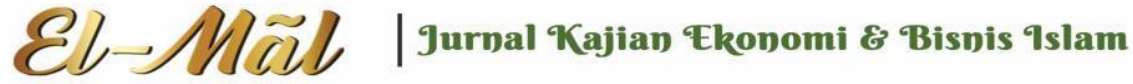

\section{Vol 4 No 1 (2021) 1-26 P-ISSN 2620-295 E-ISSN 2747-0490 DOI: $1047467 /$ elmal.v3i1.518}

Breusch-Godfrey Serial Correlation LM Test:
\begin{tabular}{llll}
\multicolumn{4}{l}{ Null hypothesis: No serial correlation at up to 2 lags } \\
\hline \hline F-statistic & 279.0609 & Prob. F(2,193) & 0.0000 \\
Obs*R-squared & 147.1241 & Prob. Chi-Square(2) & 0.0000 \\
\hline \hline
\end{tabular}

Berdasarkan gambar diatas, nilai prob.chi-square (yang Obs*R Squared) sebesar $0,00<0.05$ maka terjadi masalah autokorelasi dan harus diperbaiki. Cara memperbaiki autokorelasi dengan menggunakan metode diferensiasi tingkat pertama. Persamaan yang digunakan saat diestimasi seperti berikut:

$$
d(y 2)=c+d(x 1)+d(x 2)
$$

Keterangan:

$\mathrm{d}=$ diferensiasi tingkat pertama

$\mathrm{c}=$ konstanta

y2 = variabel dependen ( Pendidikan Nasional )

$\mathrm{x} 1+\mathrm{x} 2=$ variabel independen ( Inklusi Keuangan dan Bank Syariah)

Setelah persamaan diestimasi menggunakan metode diferensiasi tingkat pertama, maka hasilnya seperti pada tabel 19.

Tabel 19 Uji Autokorelasi setelah di diferensiasi tinggkat pertama untuk Model 2 Sumber: Data diolah menggunakan Eviews Sv 11

Breusch-Godfrey Serial Correlation LM Test:

Null hypothesis: No serial correlation at up to 2 lags

\begin{tabular}{llll}
\hline \hline & & & \\
F-statistic & 1.044141 & Prob. F(2,192) & 0.3540 \\
Obs*R-squared & 2.119610 & Prob. Chi-Square(2) & 0.3465 \\
\hline \hline
\end{tabular}

Berdasarkan tabel 4.27 diatas dapat dilihat nilai prob.chi-square (yang Obs* $\mathrm{R}$ Squared) sebesar 0,3465 $>0.05$, maka dapat disimpulkan bahwa sudah tidak terjadi masalah autokorelasi. Selanjutnya akan dilakukan uji heteroskedastisitas, langkah yang dilakukan tentu sama seperti sebelumnya yaitu menggunakan uji glejser. Hasil yang diperlukan dari uji ini adalah nilai prob.chi-square (yang $0 b{ }^{*} R$ Squared) harus lebih besar dari 0,05 .

Tabel 20 Uji Heteroskedastisitas Model 2 Sumber: Data diolah menggunakan Eviews Sv 11 


\section{Vol 4 No 1 (2021) 1-26 P-ISSN 2620-295 E-ISSN 2747-0490 DOI: $1047467 /$ elmal.v3i1.518}

\begin{tabular}{llll}
$\begin{array}{l}\text { Heteroskedasticity Test: Glejser } \\
\text { Null hypothesis: Homoskedasticity }\end{array}$ & \\
\hline \hline & 2.930692 & Prob. F(2,195) & 0.0557 \\
F-statistic & 5.777885 & Prob. Chi-Square(2) & 0.0556 \\
Obs ${ }^{*}$ R-squared & 8.442820 & Prob. Chi-Square(2) & 0.0147 \\
Scaled explained SS &
\end{tabular}

Berdasarkan hasil uji heteroskedastisitas diatas terlihat nilai prob.chi-square (yang $0 b{ }^{*} R$ Squared) sebesar 0,0556 > 0,05, sehingga dapat disimpulkan bahwa tidak terjadi heteroskedastisitas pada penelitian ini.

Analisis regresi yang telah dilaksanakan bertujuan untuk mengetahui hubungan yang dapat diukur dari Inklusi Keuangan $\left(\mathrm{X}_{1}\right)$, Bank Syariah $\left(\mathrm{X}_{2}\right)$ terhadap Kesahatan Nasional $\left(\mathrm{Y}_{1}\right)$ dan Pendidikan Nasional $\left(\mathrm{Y}_{2}\right)$. Berikut ini adalah tabel yang merangkum hubungan antara variabel independen dengan variabel dependen secara parsial.

Tabel 21 Hubungan Variabel Independen terhadap Variabel Dependen Sumber: Data diolah menggunakan Eviews Sv 11

\begin{tabular}{|c|c|c|c|c|}
\hline \multirow{2}{*}{ Variabel } & \multicolumn{2}{|c|}{ Inklusi Keuangan $\left(\mathrm{X}_{1}\right)$} & \multicolumn{2}{c|}{ Bank Syariah $\left(\mathrm{X}_{2}\right)$} \\
\cline { 2 - 5 } & Coefficient & Probability & Coefficient & Probability \\
\hline $\begin{array}{c}\text { Kesehatan } \\
\left(\mathrm{Y}_{1}\right)\end{array}$ & 0,082652 & {$[0,6945]$} & 0,512809 & {$\left[{ }^{*} 0,0623\right]$} \\
\hline $\begin{array}{c}\text { Pendidikan } \\
\left(\mathrm{Y}_{2}\right)\end{array}$ & 0,775556 & {$\left[{ }^{* *} 0,0244\right]$} & $-0,300884$ & {$[0,4818]$} \\
\hline
\end{tabular}

* Significant at $10 \%$

**Significant at $5 \%$

$* * *$ Significant at $1 \%$

Hasil dalam penelitian menunjukan bahwa Inklusi Keuangan memiliki pengaruh yang signifikan dan positif terhadap Pendidikan Nasional. Karena dalam aktivitas pendidikan tentu akan memerlukan rekening tabungan untuk digunakan sebagai alat transfer untuk pembayaran biaya pendidikan contohnya seperti di Universitas Ibn Khaldun Bogor setiap mahasiswa membayar biaya kuliahnya menggunakan rekening baik rekening sendiri maupun pihak lain. Selain itu, rekening tabungan juga digunakan untuk menabung untuk biaya pendidikan dimasa depan. Hasil ini pun serupa dengan penelitian lain yang dilakukan oleh Chiapa, C., Prina, S., \& Parker, A. (2016) yang meneliti mengenai "Dampak Inklusi Keuangan terhadap Sekolah Anak dan Aspirasi dan Harap Orang Tua". Data penelitian ini adalah data eksperimen lapangan yang ada di Nepal diantara populasi yang sebagian besar tidak memiliki rekening bank. Hasil penelitian ini adalah bahwa akses keuangan dapat membantu meningkatkan tingkat sekolah anak perempuan meskipun adanya penurunan pada anak laki-laki (penurunan tidak signifikan) dan adanya keinginan kuat terhadap pendidikan dan harapan orang tua terhadap anak-anak mereka. 


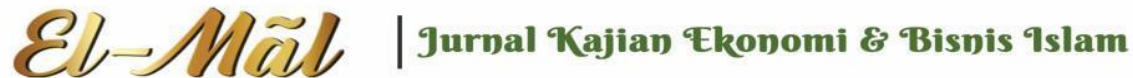

\section{Vol 4 No 1 (2021) 1-26 P-ISSN 2620-295 E-ISSN 2747-0490 DOI: 1047467/elmal.v3i1.518}

Penelitian yang dilakukan Sukmawidjaja (2018) pun sama dengan penelitian ini. Penelitian Sukmawidjaja (2018) yang berjudul "Dampak kegiatan inklusi keuangan terhadap pengembangan usaha Mikro dan kecil, pembangunan manusia (pendidikan dan kesehatan), dan pertumbuhan ekonomi di Indonesia" berkesimpulan bahwa pembiayaan mikro produktif berpengaruh posifit terhadap jumlah usaha mikro dan kecil, dan jumlah tenaga kerja mikro dan kecil. Pembiayaan qard berpengaruh positif dan signifikan terhadap angka harapan hidup dan angka partisipasi sekolah. Jumlah usaha mikro dan kecil, jumlah tenaga kerja usaha mikro dan kecil, angka harapan hidup, dan angka partisipasi sekolah berpengaruh positif dan signifikan terhadap PDB. Inklusi Keuangan memiliki pengaruh terhadap PDB Indonesia.

Hasil untuk Bank Syariah menunjukan bahwa Bank Syariah memiliki pengaruh yang signifikan dan positif terhadap sektor Kesehatan Nasional.

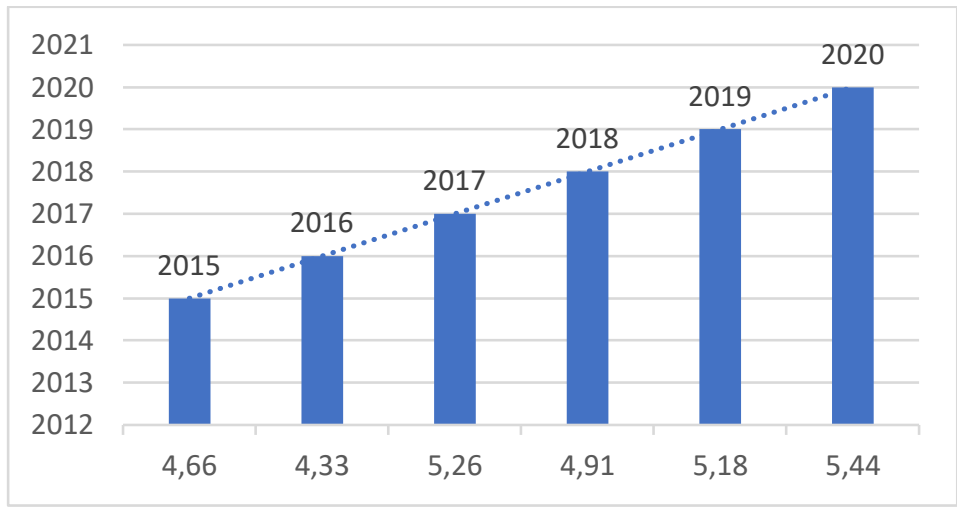

\section{Gambar 5 Unmet Need Pelayanan Kesehatan Indonesia 2015-2020 (Persen)}

Sumber: Hasil pengolahan data dari Badan Pusat Statistik

Dapat dilihat bahwasanya ada peningkatan dalam indeks unmet need pelayanan kesehatan di Indonesia pada rentang tahun 2015-2020, hal ini dapat diartikan adanya perbaikan dalam sektor kesehatan di Indonesia. Jika dilihat dari produk pembiayaan Bank Syariah Indonesia maka terdapat jenis pembiayaan BSI Multiguna Hasanah yang diperuntukkan memenuhi pembiayaan konsumtif salah satunya untuk perawatan di rumah sakit. Hasil penelitian ini berbeda dengan hasil penelitian yang dilakukan oleh Wardani (2021) yang berjudul Pengaruh Pembiayaan Bank Syariah, Zakat, dan Belanja Pendidikan, terhadap Pertumbuhan Ekonomi dan Indeks Pembangunan Manusia di Indonesia Tahun 2015-2019. Hasil analisis tersebut mengemukakan bahwa Pembiayaan perbankan syariah, zakat, dan belanja pendidikan berpengaruh positif signifikan terhadap IPM.

Hasil penelitian lain didapatkan dari penelitian yang dilakukan oleh Risyadi (2018) yang berjudul "Pengaruh pembiayaan syariah, belanja pemerintah, dan gini ratio terhadap indeks pembangunan manusia dan pertumbuhan ekonomi di Indonesia Tahun 2012-2016", mendapatkan hasil penelitian ini menjelaskan bawah pembiayaan 


\section{Vol 4 No 1 (2021) 1-26 P-ISSN 2620-295 E-ISSN 2747-0490 DOI: $1047467 /$ elmal.v3i1.518}

perbankan syariah, belanja pendidikan, dan belanja kesehatan memiliki pengaruh signifikan dan positif terhadap indeks pembangunan manusia.

Pada penelitian ini menunjukan bahwa Inklusi Keuangan tidak berpengaruh yang signifikan terhadap Kesehatan Nasional karena Inklusi Keuangan disini menggunakan indikator rekening tabungan atau dana pihak ketiga, lalu ketika seseorang ingin menggunakan fasilitas kesehatan seperti berobat ke rumah sakit ataupun puskesmas tentu tidak perlu memiliki rekening tabungan bahkan asuransi syariah atau BPJS Kesehatan bisa jadi lebih diperlukan. Hasil berbeda jika dilihat dari penelitian lain dilakukan oleh Ajefu, Demir, \& Haghpanahan (2020), yang menganalisa tentang Dampak dari Inklusi Keuangan terhadap Kesehatan Mental yang dilakukan di Nigeria dengan hasil penelitiannya bahwa inklusi keuangan dapat dianggap sebagai kebijakan penting dalam mengatasi atau mengekang kejadian gejala depresi di Nigeria, terutama jika menyangkut rumah tangga pedesaan.

Hasil yang berbeda juga pada penelitian Agustin, G. (2020) yang meneliti mengenai Analisis Pengaruh Inklusi Keuangan Terhadap Indeks Pembangunan Manusia Di Indonesia Tahun 2015-2018. Hasil analisis menunjukkan bahwa secara parsial dimensi penetrasi dan usability berpengaruh positif signifikan terhadap Indeks Pembangunan Manusia (Pendidikan dan Kesehatan) di Indonesia. Perbedaan hasil dari setiap penelitian adalah hal yang wajar meskipun variabel yang digunakan terlihat hampir sama ataupun sama. Perbedaan hasil tersebut dapat terjadi karena indikator variabel yang berbeda pada setiap penelitian.

Variabel Bank Syariah berpengaruh tidak memiliki pengaruh yang signifikan terhadap sektor Pendidikan Nasional. Karena jika dilihat dari Laporan Pembiayaan Bank Umum Syariah dan Unit Usaha Syariah berdasarkan Lapangan Usaha dan Bukan Lapangan Usaha yang bersumber dari Statistik Perbankan Syariah - OJK bahwa pembiayaan yang diterima pada sektor jasa kesehatan dan kegiatan sosial sebesar 6.563 Miliar Rupiah. Nominal pembiayaan tersebut sangat kecil jika dibandingkan dengan pembiayaan pada sektor perdagangan besar dan eceran yang menguasai pembiayaan lapangan usaha sebesar 39.936 Miliar Rupiah. Maka sangat wajar jika bank syariah tidak memiliki pengaruh signifikan terhadap sektor pendidikan nasional.

Hasil penelitian lain pun berbeda dengan hasil penelitian ini bahwa penelitian yang dilakukan oleh Risyadi (2018) yang berjudul "Pengaruh pembiayaan syariah, belanja pemerintah, dan gini ratio terhadap indeks pembangunan manusia dan pertumbuhan ekonomi di Indonesia Tahun 2012-2016", mendapatkan hasil penelitian ini menjelaskan bawah pembiayaan perbankan syariah, belanja pendidikan, dan belanja kesehatan memiliki pengaruh signifikan dan positif terhadap indeks pembangunan manusia. Hasil penelitian ini berbeda dengan hasil penelitian yang dilakukan oleh Wardani (2021) yang berjudul Pengaruh Pembiayaan Bank Syariah, Zakat, dan Belanja Pendidikan, terhadap Pertumbuhan Ekonomi dan Indeks Pembangunan Manusia di Indonesia Tahun 2015-2019. Hasil analisis tersebut mengemukakan bahwa Pembiayaan 


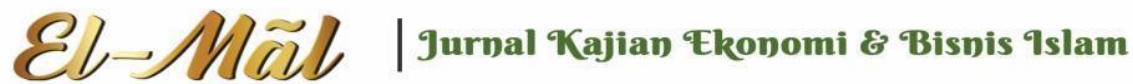

\section{Vol 4 No 1 (2021) 1-26 P-ISSN 2620-295 E-ISSN 2747-0490 DOI: 1047467/elmal.v3i1.518}

perbankan syariah, zakat, dan belanja pendidikan berpengaruh positif signifikan terhadap IPM.

\section{KESIMPULAN DAN SARAN}

Berdasarkan hasil penelitian tentang pengaruh inklusi keuangan dan bank syariah terhadap kesehatan dan pendidikan nasional, maka dapat ditarik kesimpulan diantaranya: Inklusi Keuangan tidak memiliki pengaruh yang signifikan Kesehatan Nasional. Inklusi Keuangan memiliki pengaruh terhadap yang signifikan dan positif Pendidikan Nasional. Bank Syariah memiliki pengaruh yang signifikan dan positif terhadap Kesehatan Nasional. Bank Syariah tidak memiliki pengaruh yang signifikan terhadap Pendidikan Nasional.

Berikut ini adalah beberapa saran dari penulis untuk para peneliti yang ingin melanjutkan penelitian yang berkaitan dengan penelitian ini: Untuk Perbankan Syariah disarankan agar dapat memberikan varian-varian produk yang baru agar dapat menjangkau potensi atau menjangkau bagian masyarakat yang belum dapat menjangkau inklusi keuangan syariah dan pembiayaan syariah. Bagi OJK dan Bank Indonesia penelitian ini dapat digunakan sebagai bahan pertimbangan ketika membuat strategi inklusi keuangan maupun strategi diperbankan syariah agar keduanya dapat lebih memberikan dampak pada Sustainable Development Goals (SDGs) yang artinya juga agar lebih memberikan dampak kepada masyarakat secara luas. Bagi peneliti selanjutnya sebaiknya memperpanjang periode penelitian serta menambah jumlah daerah lainnya yang ada di Indonesia atau dapat menggunakan daerah kota/kabupaten agar lebih banyak jumlah observasinya. Karena semakin banyak data observasinya akan meningkatkan kualitas penelitian beserta hasilnya.

\section{DAFTAR PUSTAKA}

Agustin, G. (2020). Analisis Pengaruh Inklusi Keuangan Terhadap Indeks Pembangunan Manusia Di Indonesia Tahun 2015. Jurnal Ilmiah Ekonomi dan Bisnis, 17(2), 121130.

Ajefu, J. B., Demir, A., \& Haghpanahan, H. (2020). The impact of financial inclusion on mental health. SSM-Population Health, 11, 100630 


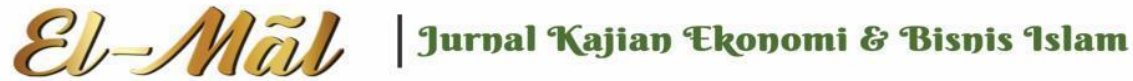

\section{Vol 4 No 1 (2021) 1-26 P-ISSN 2620-295 E-ISSN 2747-0490 DOI: $1047467 /$ elmal.v3i1.518}

Akbary, A. (2017). Pengaruh Jumlah Kunjungan Wisatawan Dan Jumlah Hotel Terhadap Pendapatan Asli Daerah (Pad) Di Kabupaten/Kota Provinsi Jawa Barat Tahun 2012-2016 (Doctoral dissertation, Universitas Pendidikan Indonesia).

Badan Pusat Statistik. (2021). Ekonomi Indonesia 2020 Turun sebesar 2,07 Persen(c-to-c). Jakarta: Badan Pusat Statistik. Diakses dari portal https://www.bps.go.id/pressrelease/2021/02/05/1811/ekonomi-indonesia2020-turun-sebesar-2-07-persen--c-to-c-.html. pada 24 Mei 2021.

Badan Pusat Statistik. (2020). Potret Pendidikan Indonesia Statistik Pendidikan 2020 Jakarta: Badan Pusat Statistik

Badan Pusat Statistik. (2019). Statistik Kesehatan 2019. Jakarta: Badan Pusat Statistik. Diakses dari portal https://www.bps.go.id/publication/2020/08/31/30154762c0baf94ee28e20c8 /statistik-kesehatan-2019.html. pada 12 Juli 2021.

Bank Indonesia. (2020). Keuangan Inklusif. Diakses dari portal https://www.bi.go.id/id/fungsi-utama/stabilitas-sistem-keuangan/keuanganinklusif/default.aspx. pada 24 Desember 2021.

Bank Indonesia. (2020). Laporan Ekonomi Dan Keuangan Syariah 2020. Jakarta: Bank Indonesia.

Chiapa, C., Prina, S., \& Parker, A. (2016). The effects of financial inclusion on children's schooling, and parental aspirations and expectations. Journal of International Development, 28(5), 683-696.

Fairuz, A. A. (2017). Pengaruh Rasio Aktivitas, Rasio Solvabilitas, Rasio Pasar, Inflasi Dan Kurs Terhadap Return Saham Syariah (Studi Pada Saham Syariah Yang Tergabung Dalam Kelompok Issi Pada Sektor Industri Tahun 2011-2015) (Bachelor's thesis, Jakarta: Fakultas Ekonomi dan Bisnis UIN Syarif Hidayatullah Jakarta).

Field, A. (2011). Discovering Statistics Using SPSS Third Edition. Los Angeles: Sage Publishing.

Google, Temasek, Bain \& Company. (2019). Fulfilling its Promise - The Future of Southeast Asia's Digital Financial Services. Diakses dari portal https://www.bain.com/insights/fufilling-its-promise/. pada 01 Juli 2021.

Hasan, L (2003). Asas - Asas Pendidikan Islam. Edisi Kelima. Jakarta: Pustaka Al Husna Baru.

Hidayat, A. (2016). Tutorial Uji Prais Winsten dengan STATA. Diakses dari portal https://www.statistikian.com/2016/10/prais-winsten-dengan-stata.html. pada tanggal 15 Juli 2021

Ibrahim, M. H. (n,d). Practical Econometrics Series \# 1 Traditional Panel Models. (Unpublished document) Kuala Lumpur : International Centre for Education in Islamic Finance (INCEIF). 


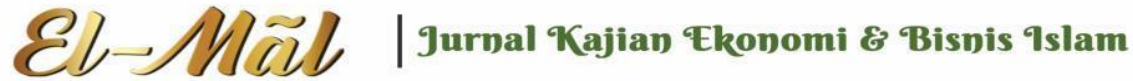

\section{Vol 4 No 1 (2021) 1-26 P-ISSN 2620-295 E-ISSN 2747-0490 DOI: $1047467 /$ elmal.v3i1.518}

Muna, M. (2019). Pengaruh Jumlah Penduduk, Pengangguran, dan Zakat Terhadap Kemiskinan (Studi Kasus di 23 Kabupaten/Kota Provinsi Aceh) (Doctoral dissertation, UIN AR-RANIRY).

OJK. (2019a). Laporan Perkembangan Keuangan Syariah Indonesia. Otoritas Jasa Keuangan, 53(9), 1689-1699.

OJK. (2019b). Bulan Inklusi Keuangan: Wujudkan Akses Keuangan Untuk Semua. Diakses dari portal https://sikapiuangmu.ojk.go.id/FrontEnd/CMS/Article/10532 pada 16 Juni 2021.

OJK. (2019c). Statistik Perbankan Syariah. Diakses dari portal https://www.ojk.go.id/id/kanal/syariah/data-dan-statistik/statistikperbankan-syariah/Default.aspx. pada 12 Juli 2021.

Peraturan Presiden No.82. "Strategi Nasional Keuangan Inklusif". Menteri Hukum dan Hak Asasi Manusia: Jakarta. 2016.

Radjab, E \& Jam'an, A. (2017). Metodologi Penelitian Bisnis. Makassar: Lembaga Perpustakaan dan Penerbitan Universitas Muhammadiyah Makassar.

Risyadi, I. I. (2018). Pengaruh pembiayaan syariah, belanja pemerintah, dan gini ratio terhadap indeks pembangunan manusia dan pertumbuhan ekonomi di Indonesia Tahun 2012-2016 (Bachelor's thesis, UIN Syarif Hidayatullah Jakarta: Fakultas Ekonomi dan Bisnis, 2018).

Satria, D. (2016). Analisis regresi: model data panel. Diakses dari portal http://www.diassatria.com/analisis-regresi-model-data-panel/ pada 13 Juli 2021

Srihardianti, M., Mustafid, M., \& Prahutama, A. (2016). Metode Regresi Data Panel Untuk Peramalan Konsumsi Energi di Indonesia. Jurnal Gaussian, 5(3), 475-485.

Simatupang, M., \& Sinaga, B. M. (2020). Impact of Financial Inclusion, Government Expenditures in Education and Health Sectors on Human Development in Indonesia. Journal of Economic Development, Environment and People, 9(2), 517.

Sustainable Development Goals. (2017). Apa itu SDGs. Diakses dari portal https://www.sdg2030indonesia.org/page/8-apa-itu. pada 10 Juli 2021

Sukmawidjaja, A. F. (2018). Dampak kegiatan inklusi keuangan terhadap pengembangan usaha Mikro dan kecil, pembangunan manusia (pendidikan dan kesehatan), dan pertumbuhan ekonomi di Indonesia. SKRIPSI-2018.

United Nations Development Programme. (2020). Human Development Reports Education Index. Diakses dari portal http://www.hdr.undp.org/en/indicators/103706 pada 16 Juni 2021. 


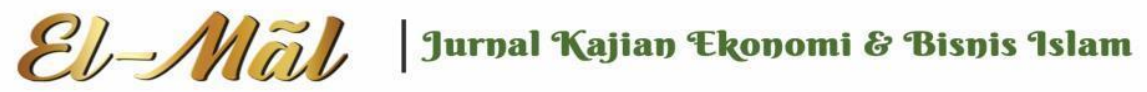

\section{Vol 4 No 1 (2021) 1-26 P-ISSN 2620-295 E-ISSN 2747-0490 DOI: $1047467 /$ elmal.v3i1.518}

United Nations Development Programme. (2020). Human Development Reports Life expectancy index. Diakses dari portal http://www.hdr.undp.org/en/indicators/103206. Pada 16 Juni 2021.

Wangsawidjaja, Z, A. (2012). Pembiayaan Bank Syariah. Jakarta: PT Gramedia Pustaka Utama. Diakses dari portal http://webadmin.ipusnas.id/ipusnas/publications/books/8359. pada 01 Juli 2021

Wahyono, T. (2009). 25 Model Analisis Statistik. Jakarta: PT Elex Media Komputindo. Diakses dari portal https://books.google.co.id/books?hl=id\&lr=\&id=k0xbDwAAQBAJ\&oi=fnd\&pg=PP $1 \& \mathrm{dq}=$ pengertian+analisis+deskriptif\&ots=hcX0HHkEtw\&sig=XA3zawlh_eGFvX6 4MBn9QUwik1I\&redir_esc=y\#v=onepage\&q=pengertian\%20analisis\%20deskrip tif\&f=false. pada 01 Agustus 2021.

Wardani, I. I. (2021). Pengaruh Pembiayaan Bank Syariah, Zakat, dan Belanja Pendidikan, terhadap Pertumbuhan Ekonomi dan Indeks Pembangunan Manusia di Indonesia Tahun 2015-2019 (Bachelor's thesis, Fakultas Ekonomi dan Bisnis uin jakarta).

World Bank. (2018). Financial Inclusion. Diakses dari portal https://www.worldbank.org/en/topic/financialinclusion/overview\#1 pada 16 Juni 2021.

World Population Review. (2021). Indonesia Population 2021 (Live). Diakses dari portal https://worldpopulationreview.com/countries/indonesia-population pada 24 Mei 2021.

World Population Review. (2021). Muslim Population By Country 2021. Diakses dari portal https://worldpopulationreview.com/country-rankings/muslim-population-bycountry pada 24 Mei 2021. 